\title{
THE PROBLEM OF THE UTILIZABILITY OF THE STARTING TEMPERATURE OF THERMAL DECOMPOSITION FOR THE EVALUATION OF THE THERMAL STABILITIES OF CO-ORDINATION COMPOUNDS
}

\author{
A. V. NiKolate and V. A. Logvinenko \\ Institute of Inorganic Chemistry, Siberian Department of the Academy of Sciences of the \\ U.S.S.R., Novosibirsk
}

(Received June 1, 1977)

\begin{abstract}
The reasons why the starting temperature of thermal decomposition cannot be utilized for the estimation of the thermal stabilities of co-ordination compounds are discussed. To establish the sequences of kinetic or thermodynamic stabilities of co-ordination compounds in thermal dissociation processes, it is indispensable to calculate the kinetic and thermodynamic parameters of the processes.
\end{abstract}

Ever since thermal analysis has been in general use for the study of synthetic co-ordination compounds, the traditional procedure for the evaluation of the "thermal stabilities" of these compounds has been based on the starting temperature of thermolysis (the temperature where DTA, TG or DTG curves begin to deviate from the zero line). In the majority of cases, thermal reactions of the type $\left[\mathrm{MA}_{6}\right] X_{2} \rightleftharpoons\left[\mathrm{MA}_{5} X\right] X+\mathrm{A} \uparrow$ are the objects of study. In these reactions, the volatile ligand is evolved, and the thermal decomposition process may be regarded as a thermally-activated solid-state process of ligand substitution. In the establishment of the sequence of thermal stabilities, conclusions are frequently made concerning the relative stabilities of the compounds or the relative strengths of the metal-ligand bonds [1-7]. Thus, the starting temperature of thermal decomposition became unduly regarded as a characteristic of the thermodynamic stability of co-ordination compounds in the thermolysis process.

The starting temperature of thermal decomposition, however, is a kinetic characteristic of the process, indicating the temperature at which the rate of the process becomes observable (recordable). This temperature largely depends on the experimental conditions, and in particular on the choice of the parameter to be measured and on the sensitivity of the thermoanalytical instrument.

Earlier studies were made on the utilizability of the starting temperature of thermal decomposition for the evaluation of the thermodynamic stabilities of compounds. It has been shown experimentally for a number of sulfates that the curves of the conventional starting temperatures $t$ of observable decomposition and the curves of the conventional temperatures $T$ of beginning thermodynamic instability proceed identically [8]. In the given case, however, it has implicitly been assumed that the curves $p$ vs. $t$ are parallel for the series of compounds (Fig. 1a) where $t_{2}>t_{1}$ if $T_{2}>T_{1}$. In principle, however, cases are possible where $p$ vs. $t$ curves intersect (Fig. 1b, c). In such cases the order of succession of stability 
with regard to the temperatures $t$ and $T$ is either totally different (Fig. 1b) or changes with changing sensitivity of the instrument or changing value of the chosen parameter $p_{\mathrm{c}}$ (Fig. 1c).

In addition, a change in the mechanism of the reaction is observable in series of analogously composed compounds (with a change of one of the ligands or the central atom) and in series of isostructural compounds, due to a change in the partial pressure of the gaseous decomposition compounds. In fact, when a standard open crucible of the derivatograph or a plate-like crucible is used, the pressure of the evolved gas changes from $\sim 0.05$ a.tm to $\sim 0.01 \mathrm{~atm}[9-11]$.

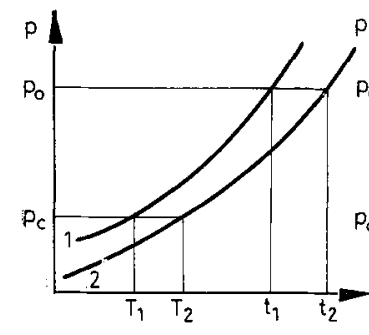

a)

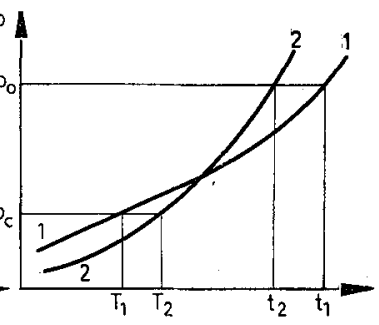

b)

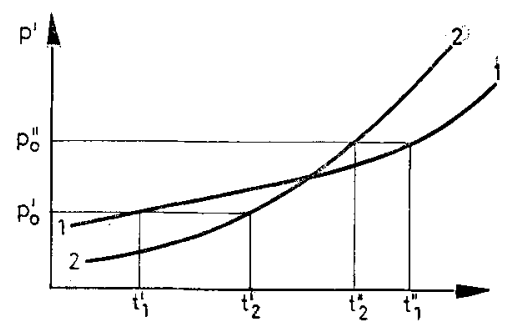

c)

Fig. 1. Possible cases of the relationship between the conventional initial temperatures $t$ of observable decomposition and the conventional temperatures $T$ of the beginning thermodynamic instability for two compounds

For addition compounds of aniline and its para-derivatives with cadmium iodide $\mathrm{CdI}_{2} \cdot 2 \mathrm{H}_{2} \mathrm{NC}_{6} \mathrm{H}_{4} X\left(X=\mathrm{H}, \mathrm{CH}_{3}, \mathrm{OCH}_{3}, \mathrm{Cl}, \mathrm{Br}\right)$ it has been demonstrated that when the standard crucible of the derivatograph is used, these compounds melt $\left(170-185^{\circ}\right)$ and decompose in the melted state by splitting off an amine. If, however, a plate-type crucible is used, the compounds decompose in one stage, splitting off the amine, without reaching the melting temperature. With the analogous chloride complexes no similar phenomenon is observed [4, 12]. 
The thermal decomposition of the complex Ni(NCS) (quinoline) $_{4} \cdot 2 \mathrm{H}_{2} \mathrm{O}$ yields $\mathrm{Ni}(\mathrm{NCS})_{2}$ (quinoline) $)_{2}$. However, two isomers can be obtained: the red isomer with a monomolecular cell, if the complex is heated in a thick layer, and the green isomer with a bridging NCS group, if the finely-ground complex is heated in a thin layer. In the first case the reaction takes place in the melt, while the second case is a solid-state reaction [13].

For a series of isostructural binuclear EDTA chelates with transition metals $\mathrm{M}_{\mathrm{I}} \mathrm{M}_{\mathrm{II}} \mathrm{L} \cdot 6 \mathrm{H}_{2} \mathrm{O}$, the dehydration process takes place similarly at any value of $p_{\mathrm{H}_{2} \mathrm{O}}$ :

$$
\mathrm{M}_{\mathrm{I}} \mathrm{M}_{\mathrm{II}} \mathrm{L} \cdot 6 \mathrm{H}_{2} \mathrm{O}=\mathrm{M}_{\mathrm{I}} \mathrm{M}_{\mathrm{II}} \mathrm{L} \cdot 5 \mathrm{H}_{2} \mathrm{O} \rightarrow \mathrm{M}_{\mathrm{I}} \mathrm{M}_{\mathrm{II}} \mathrm{L}
$$

For $\mathrm{Zn}_{2} \mathrm{~L} \cdot 6 \mathrm{H}_{2} \mathrm{O}$, however, this stepwise process takes place only at $p_{\mathrm{H} . \mathrm{O}} \leq$ $\leq 0.2$ atm. At $p_{\mathrm{H}_{2} \mathrm{O}}=1$ atm the mechanism changes:

$$
\mathrm{Zn}_{2} \mathrm{~L} \cdot 6 \mathrm{H}_{2} \mathrm{O} \rightarrow \mathrm{Zn}_{2} \mathrm{~L} \cdot \mathrm{H}_{2} \mathrm{O}
$$

and the monohydrate is stable up to $>300^{\circ}$, where the destruction of the organic ligand takes place.

These examples demonstrate that in some cases only slight changes in the partial pressure of the split-off ligand may change the mechanism of reversible dissociation processes of co-ordination compounds.

Although experimental conditions can be standardized for a given series of compounds, the combination of the thermodynamic and kinetic characteristic of the thermal decomposition will always be indefinite. Owing to the different reversibilities of the reactions (not usually studied), a change in $p_{\text {ga: }}$ will affect the temperature range of the thermolysis to a different extent for different compounds. All this will result in obtaining different sequences of thermal stability for different (but each time standardized) experimental conditions of thermal analysis.

A realistic evaluation of the thermodynamic and kinetic stabilities of co-ordination compounds in thermal reactions accompanied by the evolution of a volatile ligand can only be based on the calculation of kinetic and thermodynamic parameters of isostructural series of compounds. Energetic parameters of thermolysis processes will involve the rearrangement of the whole compound, so that no information on the strength of the metal-ligand bond can be obtained from them.

The term "thermal stability" (if determined from the temperature range of the process) does not carry - owing to the indeterminate character of its content any other quantitative value concerning the process than the statement that under the chosen experimental conditions the reaction rates at the starting temperatures of thermal decomposition are equal for compound under investigation.

\section{References}

1. G. Liptay, E. Papp-Molnár and K. Burger, J. Inorg. Nucl. Chem., 31 (1969) 247.

2 T. A. Malkova and V. N. Shafransky, Zh. Fiz. Khim., 49 (1975) 2805.

3. V. N. Shafransky and T. A. Malkova, Zh. Obshch. Khim., 46 (1976) 1197. 
4. A. V. Ablov and V. Ya. Ivanova, 5th All-Union Conference on Thermal Analysis, Novosibirsk, 1973. Collection of the papers, p. 78. (in Russian).

5. L. K. Shubochkin, V. I. Gushchin and E. F. Shubochkina, 5th All-Union Conference on Thermal Analysis, Noyosibirsk, 1973. Collection of the papers, p. 146. (in Russian).

6. E. M. Belousova, I. I. Seyfullina, V. N. Tkachenko and R. G. Yankelevich, 12th All-Union Chugaev Conference on the Chemistry of Coordination Compounds, Novosibirsk 1975. Collection of the papers, Part 3, p. 504. (in Russian).

7. V. P. Khramov, V. G. Egorova and A. A. Koltsov, 12th All-Union Chugaev Conference on the Chemistry of Coordination Compounds, Novosibirsk 1975. Collection of the papers, Part 3, p. 515. (in Russian).

8. E. V. Margulis and G. I. Chufarov, Zh. Fiz. Khim., 45 (1971) 1261.

9. J. Paulik and F. Paulik, Anal. Chim. Acta, 60 (1972) 127.

10. F. PaUlik and J. PaUlik, Thermochim. Acta, 4 (1972) 189.

11. F. Paulik and J. Paulik, J. Thermal. Anal., 5 (1973) 253.

12. A. V. Ablov, V. YA. Ivanova and V. M. Bobrinsky, Zh. Neorgan Khim., 13 (1968) 1066.

13. T. Sramko and E. Iona, Collection Czech. Chem. Commun., 37 (1972) 1645.

RÉsumé - On discute les raisons pour lesquelles on ne peut pas se servir de la température du début de la décomposition thermique pour estimer la stabilité thermique des composés de coordination. Pour établir l'ordre de succession des stabilités des composés de coordination dans les processus de dissociation thermique, il est indispensable de calculer les paramètres cinétiques et thermodynamiques des phénomènes.

Zusammenfassung - Der Grund, weshalb die Ausgangstemperatur der Thermolyse nicht zur Schätzung der Thermostabilität von Koorđinationsverbindungen eingesetzt werden kann, wird erörtert. Um die Reihenfolge der kinetischen oder thermodynamischen Stabilität von Koordinationsverbindungen in thermischen Dissoziationsvorgängen zu ermitteln ist es unumgänglich die kinetischen und thermodynamischen Parameter der Vorgänge zu errechnen.

Резюме - Рассмотрены причины, по которым температура начала термолиза не может быть использована для оценки термической устойчивости координационных соединений. Для построения рядов кинетической или термодинамической усройчивости координационных соединений в процессах термической диссоциации необходим расчет кинетических и термодинамических параметров процессов. 